\title{
Impression procedures for removable partial dentures
}

\author{
Yu-Ri Heo, Mee-Kyoung Son* \\ Department of Prosthodontics, School of Dentistry, Chosun University, Gwangju, Republic of Korea
}

To fabricate removable partial denture which provide patient's comfort and maintain oral health, cast fabrication which reproduce anatomical and functional state of mouth is needed. Diagnostic cast and master cast are produced through the process of preliminary impression and final impression taking. Both of remaining teeth and edentulous area should be well taken in removable partial denture impression. According to the supporting type of partial denture, impression material and method can be changed. Therefore, understanding of impression procedure is essential for the accurate clinical application. (J Dent Rehabil Appl Sci 2014;30(2):152-8)

Key words: removable partial denture; diagnostic cast; master cast; preliminary impression; final impression

\section{서론}

보철치료에서 인상(impression)은 구강조직의 음형 (negative form)을 채득하여 환자의 구강상태를 모형으 로 재현하기 위한 목적으로 시행한다. 특히, 구강 내 보철 물을 지지하는 지지 조직의 정확한 재현은 보철물 제작 에 있어 가장 기본적이며 필수적인 임상 과정 중의 하나 이다.

일반적으로 고정성 보철의 경우에서 인상은 삭제된 치 아의 해부학적 형태를 단순히 채득(impression taking)하 는 과정이라면, 총의치에서 인상은 무치악부의 해부학 적 형태뿐 아니라 기능시의 움직임을 술자의 의도에 의 해 적절하게 만드는(impression making) 과정이라고 할 수 있다. 반면, 가철성 국소의치의 경우는 잔존치아와 무 치악부가 공존해 있으므로 고정성과 총의치 제작을 위한 인상 개념이 모두 적용되어야 한다(impression taking + impression making)(Fig. 1). 또한, 환자 증례에 따라 치아 및 조직 지지가 다르고 또 결손 정도에 따라서도 지지 범

*Correspondence to: Mee-Kyoung Son, DDS, MSD, PhD Department of Prosthodontics, School of Dentistry, Chosun University Philmoon Daero 303, Dong-gu, Gwangju, 501-759, Republic of Korea Tel: +82-62-220-3825, Fax: +82-62-227-2363, E-mail: son0513@chosun.ac.kr Received: March 16, 2014/Last Revision: April 20, 2014/Accepted: April 25, 2014
위가 각기 다르기 때문에 증례에 따라 적절한 인상 재료 나 방법이 선택, 적용되어야 하므로 이론적으로나 임상 적으로 더 어렵고 복잡하게 인식되고 있다.

건강한 잔존치아와 치조점막을 유지하고 구강 내에서 잘 기능하는 가철성 국소의치 제작을 위해서는 무엇보다 도 구강의 형태와 기능을 정확하게 채득하는 과정이 필

\section{Impression}

- Anatomic impression

- Functional impression

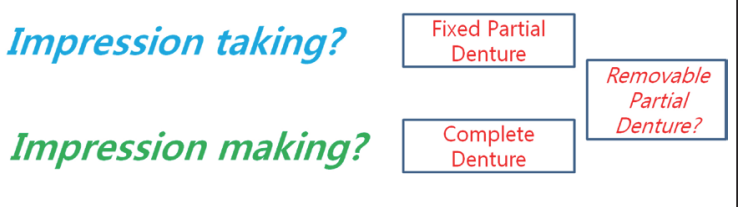

Fig. 1. Concept of impression according to the support.

Copyright(C 2014 The Korean Academy of Stomatognathic Function and Occlusion. (c) It is identical to Creative Commons Non-Commercial License. 
요하며 이를 위해서는 인상재 및 지지에 따른 인상채득 방법에 대한 이해가 우선되어야 한다. ${ }^{1}$ 따라서, 국소의 치의 예비인상, 치아지지 국소의치와 치아-조직지지 국 소의치에서의 인상채득의 차이, 그리고 주모형 인상채 득 시 1회법 인상과 2회법 인상에 대해 설명하고자 한다.

\section{본론}

\section{1. 국소의치 예비인상 (Preliminary impression)}

초진이나 보철치료의 첫 단계에서 시행하는 예비인 상의 채득은 정확한 진단모형 제작을 위한 과정이다. 국 소의치 치료에서 진단모형은 단순히 구강내 상태를 진 단하는 도구로 사용되는 것 외에도 육안검사 및 써베잉 을 통해 국소의치 설계 및 치료계획을 수립하기 위한 지 형적 정보를 제공하므로 다른 치료 계획시 보다도 더 정 확성이 요구된다. 가철성 국소의치 환자에서 치아의 해 부학적 인상과 조직의 기능적 인상에 대한 고려는 주모 형 제작을 위한 최종 인상 뿐 아니라 예비인상에서도 적 용되어야 한다. 또한, 정확한 예비 인상채득을 위해서는 재료와 방법에 대해 이해하고 적용하는 것이 필요하다. ${ }^{2}$

1) 트레이(Tray) 선택과 조정

트레이는 최대한 해부학적 구조를 포함하도록 악궁 의 크기보다 4-6 mm 정도 큰 사이즈를 선택한다. ${ }^{3}$ 너 무 큰 사이즈를 선택하면 예비인상이 과연장(overextension)되어 채득될 수 있고 이는 형성된 진단모형에서 맞 춤형 트레이 제작 시 많은 조정이 필요하거나 최종인상 의 과연장을 야기할 수 있다. 총의치 인상은 흡착을 위 한 변연 봉쇄를 위해 생리적 과연장을 허용하지만, 국소 의치는 변연이 과연장되면 오히려 의치를 밀어내 지대 치에 무리를 줄 수 있어 권장되지 않는다(Fig. 2). 따라 서 기성 트레이를 조정하여 예비인상 채득부터 과연장 되지 않도록 주의해야 한다. ${ }^{3}$ 기성 플라스틱 트레이(Fig. $3 \mathrm{~A}$ )로 인상채득시 Fig. $3 \mathrm{~B}$ 의 화살표에서 보이는 것과 같
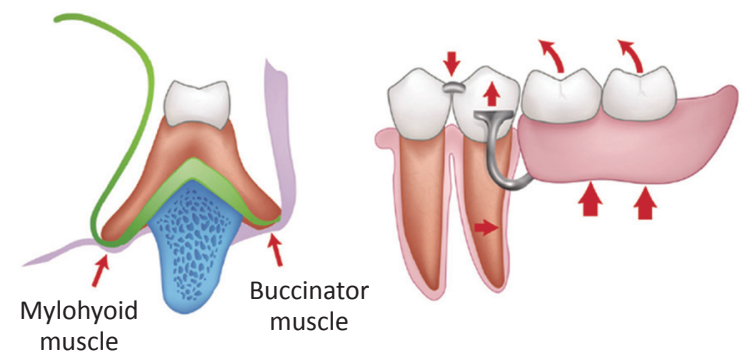

Fig. 2. Partial denture impressions are not to be overextended unlike for the full denture impressions. ${ }^{3}$
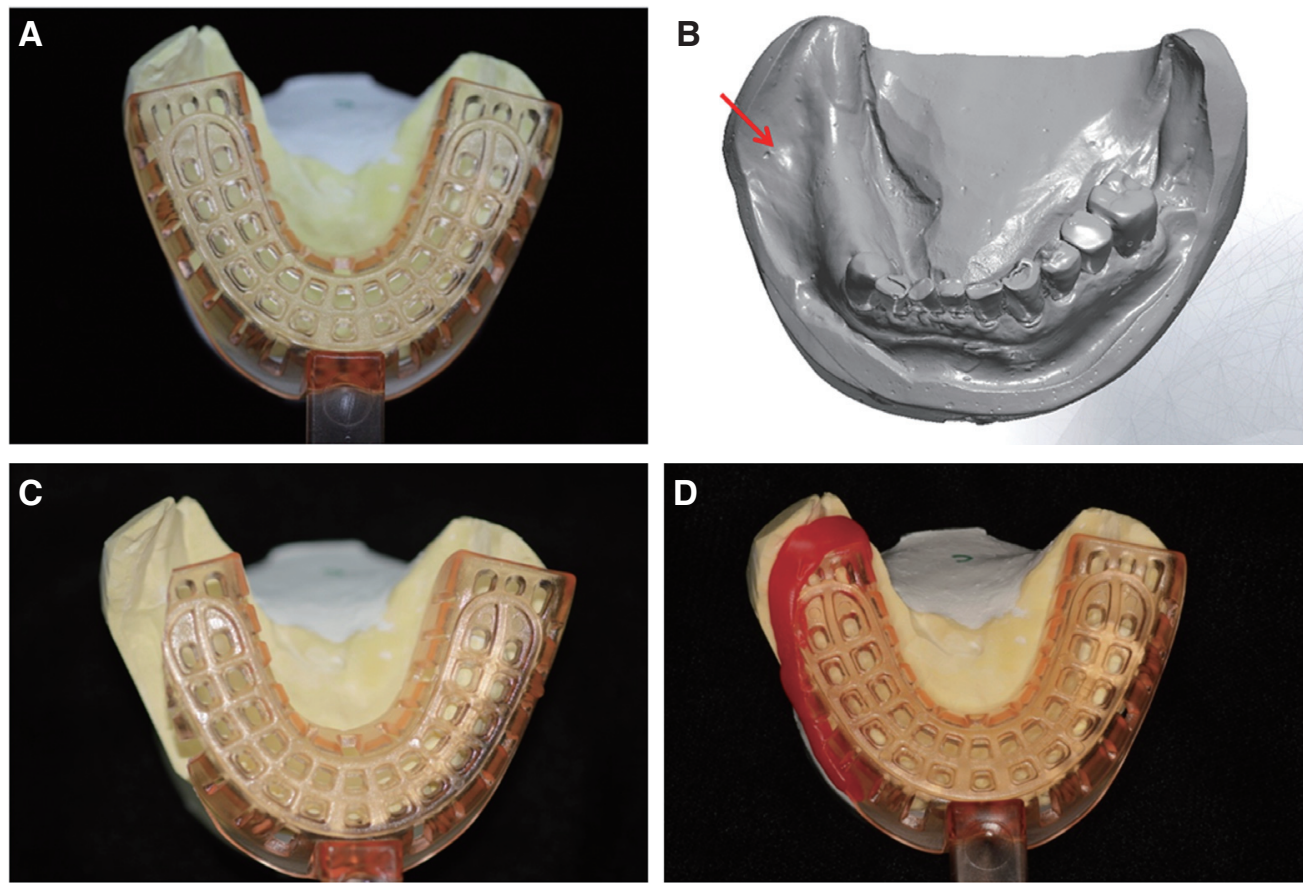

Fig. 3. Adjustment of ready-made plastic tray. Arrow indicates overextension of buccal vestibule by using ready-made tray. 
이 협측 부분이 과연장될 가능성이 있다. 따라서 트레이 의 협측을 제거하고(Fig. $3 \mathrm{C}$ ) 왁스를 협측과 길이가 짧 은 후구개 삼각(retromolar pad)부위까지 연장되도록 추 가한 후 연화(Fig. $3 \mathrm{D}$ )하여 구강 내에서 적절한 모양이 되도록 한다. 플라스틱 트레이 중 형상 기억 재질을 사 용하여 뜨거운 물에 넣은 후 손으로 원하는 부분을 구부 리거나 펴서 환자에게 맞는 모양으로 조정한 후 찬 온 도에서 유지되는 트레이도 사용될 수 있다. 이러한 특수 재질의 트레이는 설측 후방부에서 후악설골와(retromylohyoid fossa)로 구부러지는 부분의 정확한 인상을 인 기하는데 도움이 된다(Fig. 4).

\section{2) 예비인상 재료 및 방법}

정확한 교합진단 모형제작을 위해 예비인상 채득에 실리콘 계열의 고무 인상재를 사용하기도 하지만 대부 분 알지네이트 인상재를 사용한다. 알지네이트는 맞춤 형 트레이가 필요 없고 환자의 불편함을 줄일 수 있으며 가격이 저렴한 장점이 있는 반면, 찢김 강도가 작고 표 면 재현성이 고무 인상재보다 떨어지는 단점이 있다. 또 한, 팽윤과 이액현상으로 인한 인상체의 부정확성이 있 을 수 있으므로 취급 시 주의가 필요하다.

인상채득은 기술과 재료에 매우 민감하다. 따라서 재 료의 성질을 잘 파악하고 숙련된 기술을 사용할 때 가 장 정확한 인상채득이 가능하다. 알지네이트를 이용한 인상채득 시 우선 환자 구강 내 이물질이 없도록 입안 을 세척하도록 한다. 이때 너무 차거나 뜨거운 물로 헹 구게 하면 타액분비가 증가될 수 있고 구토반응이 유발 될 수 있으므로 체온과 비슷한 온도의 물을 사용하도록 한다. 또한 환자를 이완시키기 위해 구토반사가 빈번한 상악보다는 하악을 우선적으로 채득한다. 알지네이트는 균일한 크림형상이 되도록 혼합하고 물 온도는 18 - 24
도가 적절하다. 물 온도가 1 도 낮아지면 경화시간이 6초 정도 느려지므로 물 온도를 통해 경화시간을 조절할 수 있다. 최근 자동 혼합기의 사용은 균일한 혼합을 도우나 경화시간이 약간 빨라지는 경향이 있으므로 이에 대한 고 려가 필요하다. 알지네이트는 정상경화형과 급경화형이 있으며 경화시간은 경화 타입에 따라 1 - 5분 정도이다. ${ }^{4}$

인상을 채득할 때에는 환자가 긴장하지 않도록 앉은 자세에서 시행하며 상악은 환자의 뒤에서, 하악은 환자 의 앞에서 채득한다. 상악은 후방부위부터, 하악은 전방 부위부터 먼저 안착하고 혀를 들게 한 후 후방부위를 더 깊이 위치시킨다. 깊은 구개 및 전정 부위, 구강저는 별 도의 시린지를 사용하거나 손가락으로 알지네이트를 적 용하는 것이 추천된다.

경화 후 여분의 알지네이트가 손에 묻어나지 않으면 2 - 3분 기다렸다 인상체를 환자 구강으로부터 제거한 다. 인상체를 제거할 때에는 빨리 한 번에 제거해야 찢 김 강도가 증가하며 석고는 즉시 또는 최소 10 분 이내에 부어야 변형이 적다(1시간 내 $0.44 \%$ 수축). 모형의 제거 는 40 분 - 1 시간 후에 제거해야 모형이 깨끗하게 제작된 다. ${ }^{4}$

\section{2. 국소의치 주모형 인상(Final impression)}

진단모형에서 조직 및 치아의 언더컷, 삽입 철거로를 고려한 계획이 세워지고 구강 형성이 국소의치 제작 전 단계까지 시행된 후 국소의치 금속구조물(metal framework) 제작을 위한 인상채득이 필요하다. 국소의치 주 모형을 위한 인상은 국소의치의 지지 형태에 따라 다른 방법이 사용될 수 있다.

일반적으로 치아지지 국소의치는 해부학적 형태의 인 상만으로도 가능한 반면, 치아-조직 지지 국소의치는 기
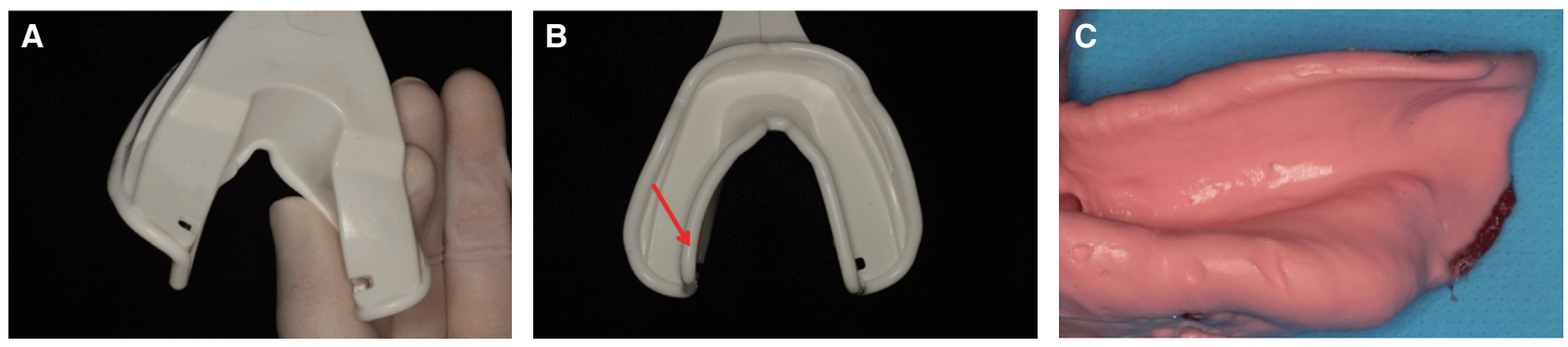

Fig. 4. Adjustment of plastic tray which is made by shape memory material. 
능적 인상이 동시에 채득되어야 한다. 따라서 우선적으 로, 국소의치 증례를 치아지지와 치아-조직 지지로 분류 하는 것이 필요하다.

1) 치아지지 국소의치와 치아-조직 지지 국소의치 국소의치의 분류는 누구나 쉽게 분류에 따라 형태를 예측할 수 있어야 하므로 주로 케네디 분류(Kennedy classification)를 주로 사용한다. 케네디 분류에 따른 국 소의치의 증례는 일반적으로 지지 영역에 따라서 후방 연장 국소의치인 Class I과 II는 치아-조직 지지로, Class $\mathrm{III}$ 는 치아 지지 국소의치로 고려된다. 하지만, 실제로는 케네디 분류법만으로는 주 지지 부위에 대해 명확히 알 기는 힘들다. 예를 들자면, Class III라 하더라도 결손된 치아 수가 많고 결손부 인접 치아가 약한 경우는 조직 지지가 부가적으로 필요할 수 있기 때문이다. 즉, Class III나 IV의 증례에서도 너무 많은 치아 결손으로 인해 의치의 지지가 치아와 조직에서 동시에 얻어져야 한다 면 해부학적 인상만으로는 어렵고 기능인상의 채득이 필요하다.

2) 후방연장 국소의치의 인상

후방연장 국소의치는 각기 변위량이 다른 치아와 조 직이 의치의 지지를 분담하므로 기능시 회전축을 통한 동요가 발생된다. ${ }^{5,6}$ 따라서 국소의치 설계의 원칙은 기 능시 의치의 동요를 최소화하고 지대치에 가해지는 외 력(torque)을 감소시키는 것이다. 국소의치의 과도한 움 직임을 줄이는 방법은 각 구성요소들을 적절한 위치에 정확하게 설계하는 것이다. 이와 더불어, 정확한 인상채

\section{Methods to minimize denture mobility during function and reduce the torque to abutment teeth}

1. Understanding of rotational movement of partial denture during function

2. Correct position and design of partial denture components

3. Accurate Impression Taking

Support

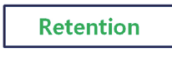

Stability

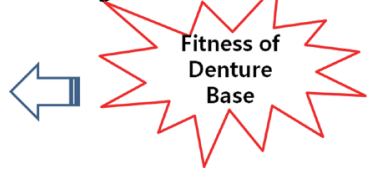

Fig. 5. Fitness of denture base can be obtained by accurate impression.
득을 통한 의치상과 조직의 적합성은 의치의 안정과 지 지, 유지에 중요한 역할을 하여 의치의 동요를 줄일 수 있으므로 매우 중요하다(Fig. 5).

\section{3) 국소의치 주모형 인상재}

인상재는 사용이 편리하고 조작과 경화시간, 가격이 적절해야 하며 술자의 숙련도와 정확한 기술에 따라 선 택될 수 있다. ${ }^{3,7,8}$ 일반적으로 주모형 제작에 사용하는 인 상재는 알지네이트, 부가중합형 실리콘(polyvinyl siloxane), 폴리설파이드(polysulfide)가 있다.

알지네이트는 진단모형을 위한 예비인상과 금속구조 물 제작을 위한 주모형 인상 모두에 사용될 수 있다. 이 는 표면 재현성이 고무인상재보다 떨어지지만 맞춤형 트레이가 필요 없고 찢김 강도가 작아 오히려 변형없이 언더컷을 빠져 나올 수 있는 장점이 있다. 하지만, 경화 시간이 빨라 무치악 부분의 기능인상을 위한 재료로는 적절하지 않으므로 알지네이트를 이용해 주모형을 만든 경우는 국소의치 금속구조물 제작 후 개조모형(altered cast)제작을 위한 이차 인상이 필요하다.

부가중합형 실리콘은 중등도 이상의 찢김 강도를 가 지므로 언더컷을 빠져 나오면서 잘 찢기지 않고 변형도 적은 장점이 있다. 제품에 따라 다양한 점도가 제공되고 있으므로 조직의 성상에 따라 적절한 점도를 선택하여 사용할 수 있다. 또한 최근에는 변연형성(border molding)이나 무치악 인상용 실리콘 인상재가 공급되고 있으 므로 편리하게 사용할 수 있다.

폴리설파이드는 찢김 강도가 크고 충분한 작업시간 으로 인해 무치악 기능인상에 가장 많이 사용하는 재료 이다. 하지만, 치아가 함께 있는 국소의치 인상에서 폴 리설파이드의 높은 찢김 강도는 오히려 단점으로 작용 할 수도 있다. 즉, 치아 총생이 있거나 치주질환으로 인 해 치아 사이의 공극이 큰 경우 인상체를 제거할 때 치 간 사이로 들어간 폴리설파이드가 걸려서 찢어 지지 않 고 늘어지는 성향 때문에 변형을 야기할 수 있다. 따라 서, 치아가 많은 경우 또는 치주질환으로 치간공극이 큰 경우에서는 추천되지 않는다. ${ }^{3}$

\section{4) 1 회법 인상과 2회법 인상}

국소의치는 증례에 따라 1회법 인상이나 2회법 인상 채득 방법을 사용하여 제작할 수 있다. 1 회법을 통해 제 작하는 경우는, 진단모형에서 맞춤형 트레이를 만들어 총의치 인상과 유사하게 치아와 조직을 함께 기능인상 
을 채득하고 주모형을 만들어 국소의치 금속구조물과 의치상을 제작하는 방법이다(Fig. 6). 반면, 2 회법 인상 을 이용한 방법이란 금속구조물 제작과 의치상 부위의 제작을 위해 두 번의 인상채득이 필요한 방법이다. 즉, 인상채득을 통해 주모형을 제작한 후 금속구조물을 일
차적으로 만든 다음, 무치악 부분의 맞춤형 트레이를 금 속구조물에 연결하고 구강 내에 장착하여 조직 부위의 이차적 기능인상을 채득하고 개조모형을 제작하여 의치 상 부분을 완성하는 방법이다(Fig. 7).

일반적으로 상악은 1 회법 인상을 추천한다. 이는 상악

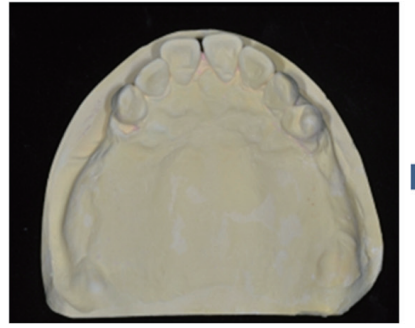

Diagnostic Cast

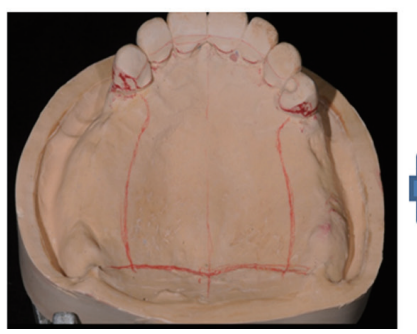

Master Cast

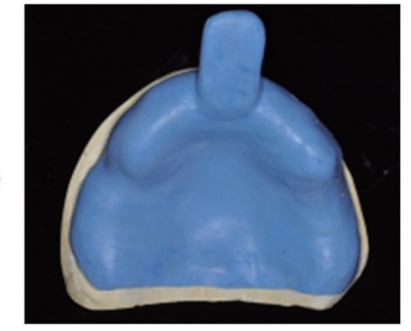

Individual Tray

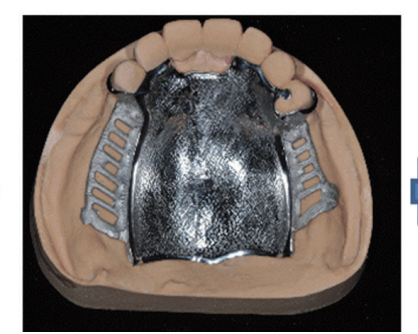

Framework Fabrication
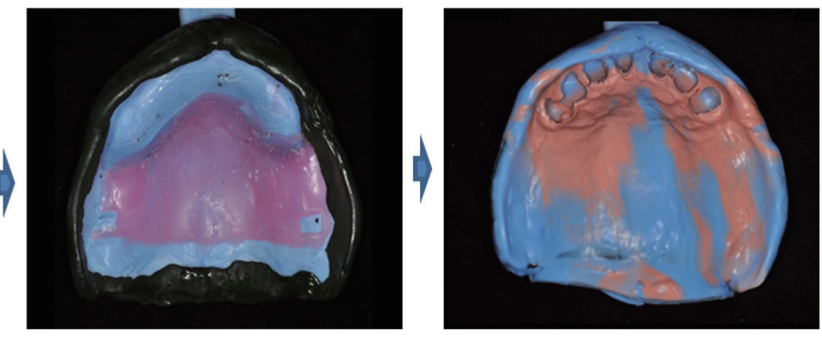

Border Molding \& Functional Impression

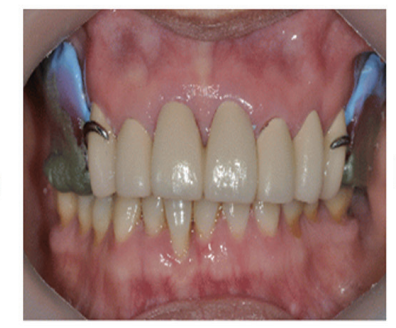

Bite Registration

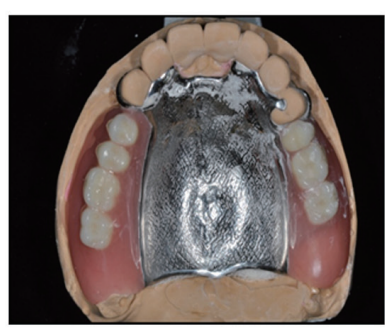

Final Denture Fabrication

Fig. 6. Removable partial denture fabrication by full arch functional impression method.

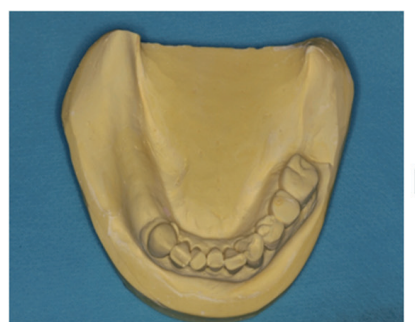

Diagnostic Cast

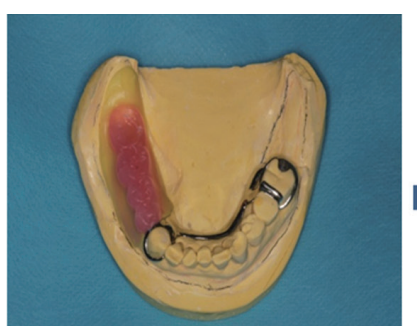

Framework Fabrication

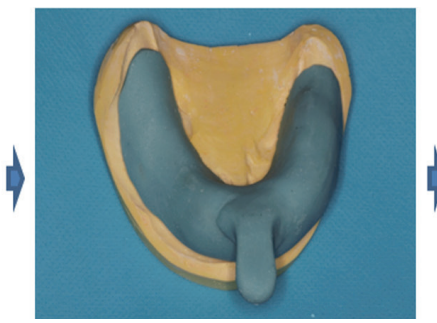

Individual Tray

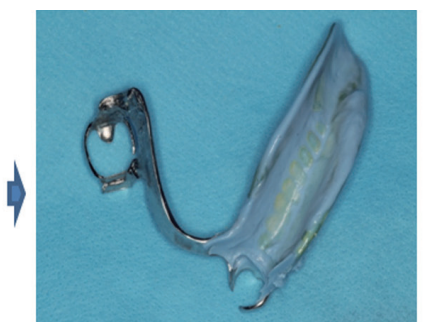

Impression for Distal Extension Part
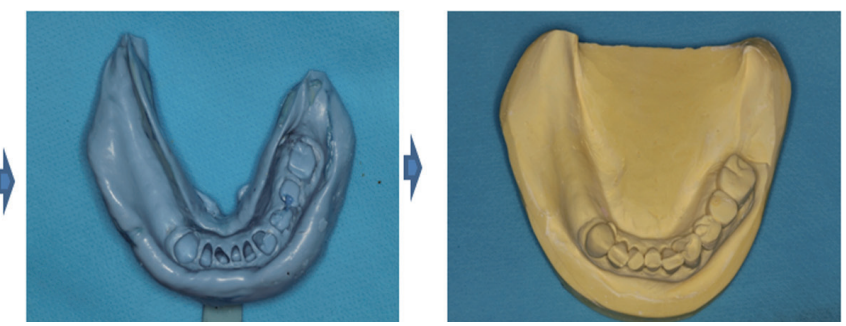

Functional Impression \& Master Cast
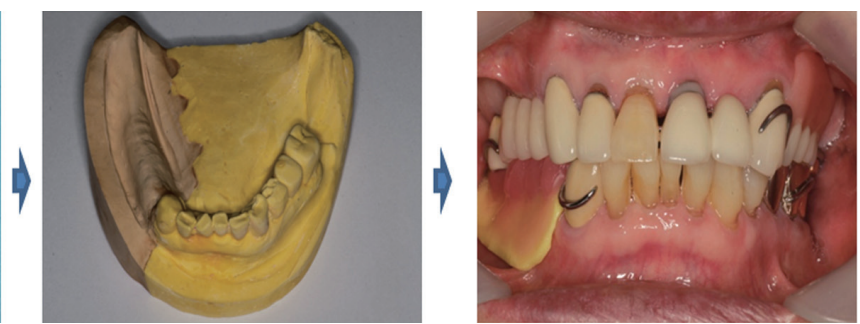

Altered Cast
Bite Registration \& Denture Fabrication

Fig. 7. Removable partial denture fabrication by altered cast impression method. 
의 점막이 단단하여 조직 변위가 적으므로 굳이 조직부 인상을 다시 채득하지 않아도 되며 또한, 개조모형 제작 시 오히려 구개측으로 석고가 흘러가거나 레스트가 뜨 는 등의 문제가 야기될 수 있기 때문이다. 따라서, 작업 모형에서 개인 트레이를 만들고 인상재를 이용해 1회법 인상을 채득하여 주모형을 제작하여 국소의치를 완성 한다.

하악은 다수 치아의 상실로 남아있는 잔존치의 개수 가 6개 이하인 경우, 금속구조물을 만들어 이차인상을 채득하게 되면 금속 구조물에 너무 큰 트레이가 부착되 어 안정적인 인상채득이 어렵다. 이런 경우에는 총의치 에 준하는 1 회법 인상을 채득하여 국소의치를 제작한 다. 하지만, 일반적으로 하악의 치아-조직 지지 국소의 치의 경우는 주모형 인상에서 금속구조물을 만들고 후 방 조직부분은 다시 기능인상을 채득하여 개조모형을 제작하여 의치상을 제작하는 2 회법 인상채득 방법이 가 장 우수한 적합성을 보이므로 추천될 수 있다..$^{8-10}$

\section{결론}

환자의 증례별로 다양한 구강 내, 외적인 요소들을 고 려하여 구강 내에서 잘 기능하고 환자에게 불편이 적으 며 치아나 조직의 건강에 유리한 국소의치 제작을 위해 서는 치료의 시작단계인 진단과 치료계획 과정이 매우 중요하다. 예비인상을 통한 진단모형의 제작, 그리고 진 단모형의 검사를 통한 구강형성 및 국소의치 구성요소 의 설계는 국소의치의 성공적인 치료의 시작이며 치료 과정 중 가장 중요한 과정이라 해도 과하지 않다.

국소의치의 인상채득은 국소의치의 기능과 수명에 큰 영향을 미친다. 국소의치의 다양한 증례가 존재하는 것 처럼, 잔존치아의 상태나 조직의 상태, 지지 영역, 금속 구조물의 안정성 여부에 따라 적절한 인상재의 선택과 인상방법에 대한 고려가 충분히 이루어질 때 의치의 지 지, 안정, 유지가 향상되고 구강 내에서 적절히 기능하 는 정확한 국소의치 제작이 가능하다.

\section{Acknowledgements}

이 논문은 2013년도 조선대학교 학술연구비의 지원을 받아 연구되었음.

\section{References}

1. Carr AB, McGivney GP, Brown DT. McCraken's removable partial prosthodontics. $11^{\text {th }}$ ed. St. Louis; Elsevier Mosby; 2005. p. 275-300.

2. Nandini VV, Venkatesh KV, Nair KC. Alginate impressions: a practical perspective. J Conserv Dent 2008;11:37-41.

3. Kwak JY, Kim SJ, Kim SG, Kim YR, Park JM, Kim JH, Park YB, Bang MS, Son MK, Shin SY, Ahn SJ, Lee SW, Lee SB, Lee JI, Lim HP, Cho RR, Cho SA, Cho JH, Han DH, Heo SJ, Heo JB. Removable partial prosthodontics. $1^{\text {st }}$ ed. Seoul; Yenang Inc; 2012. p. 268-305.

4. Korean Association of Dental Materials Professors. Dental materials. $6^{\text {th }}$ ed. Seoul; Koonja; 2011. p. 113-144.

5. Preston KP. The bilateral distal extension removable partial denture: mechanical problems and solutions. Eur J Prosthodont Restor Dent 2007;15:11521.

6. Leupold RJ, Kratochvil FJ. An altered-cast procedure to improve tissue support for removable partial dentures. J Prosthet Dent 1965;15:672-8.

7. Christensen GJ. Impression materials for complete and partial denture prosthodontics. Dent Clin North Am 1984;28:223-37.

8. Rubel BS. Impression materials: a comparative review of impression materials most commonly used in restorative dentistry. Dent Clin North Am 2007;51:629-42.

9. Frank RP, Brudvik JS, Noonan CJ. Clinical outcome of the altered cast impression procedure compared with use of a one-piece cast. J Prosthet Dent 2004; 91:468-76.

10. Sajjan C. An altered cast procedure to improve tissue support for removable partial denture. Contemp Clin Dent 2010;1:103-6. 


\section{가철성 국소의치 제작을 위한 인상채득}

\section{허유리, 손미경*}

조선대학교 치의학전문대학원 보철학교실

저작기능의 회복과 더불어 환자에게 편안함을 제공하며 잔존치아와 치조점막을 건강하게 유지할 수 있는 가철성 국소 의치 제작을 위해서는 구강내의 형태적, 기능적 상태를 재현하는 모형제작이 필수적이다. 국소의치 제작을 위해서는 진단모형과 주모형의 제작이 필요하며 이를 위해서 예비인상과 최종인상 채득 과정을 거치게 된다. 국소의치의 인상채 득은 고정성이나 총의치 인상과 다르게 치아부위와 조직부위 모두가 잘 인기되어야 하고 치아 결손 부위에 따라 교합 을 지지하는 부위가 달라지므로 증례에 따른 적절한 인상재와 인상채득 방법에 대한 이해를 바탕으로 정확한 임상적 적용이 요구된다.

(구강회복응용과학지 2014;30(2):152-8)

주요어: 가철성 국소의치; 예비인상; 진단모형; 최종인상; 주모형

*교신저자: 손미경

(510-825) 광주광역시 동구 필문대로 303 조선대학교 치의학전문대학원 보철학교실

Tel: 062-220-3825 | Fax: 062-227-2363 | E-mail: son0513@chosun.ac.kr

접수일: 2014년 3월 16일 | 수정일: 2014년 4월 20일 | 채택일: 2014년 4월 25일 